\title{
THE PROBLEM OF “PRODUCTION" OF THE LOCAL CULTURAL AND ARTISTIC AREA (FROM DIAGNOSIS TO MODELING): EXPERIENCE OF RIVNE REGION
}

\section{Vitkalov S. V.}

\section{INTRODUCTION}

The cultural situation in Ukraine and regions in conditions of new social and economical formation is analyzed. The specific of cultural life organization, its leading forms and tendencies in different periods of the modern age are revealed. In order to identify the cultural activity of the artistic intellectuals in region, study of All-Ukrainian sociological research, conducted by the method of prof. O. Semashko (Kyiv) ${ }^{1}$, including in Rivne region. The attitude of the artistic intellectuals of region to art, its role in the cultural area, forms of stimulation and other factors that contribute (or do not contribute) to the development of a complete cultural process are revealed. Series of events organized by the artistic intellectuals of Rivne, aimed at improving the situation in the cultural area, based on published data of this study, are considered. Their spiritual potential and role in change of cultural situation are revealed.

\section{The artistic life of small towns from a viewpoint of sociological research}

The cultural and artistic area of modern Ukraine is a complex artistic structure, in the center of which with variety of concerts and exhibition activities is bursting, a powerful artistic encirclement is functioning. They stimulate the demand for artistic production and discussion of these issues. Although real artistic discoveries almost never or rarely happen, it's incorrect to speak about "cultural calmness". At the same time in regions everything looks different: in powerful cultural centers of Lviv or Kharkiv level the situation is the same, where the intellectuals concentrate around academic theaters, art schools, concert halls, art galleries, where they are exhibited as classics' works, as well as exhibitions of their former graduates or other well-known painters or brush cutters who are trying to gain the sympathy of art-educated audiences and art critics and thus not only self-actualize in the artistic environment of the republic, but also have good artistic reputation in a form of art exhibitions or

${ }^{1}$ O.M. Семашко, В.М. Піча, О.І. Погорілий. Соціологія культури: навч. посібник. За ред. О.М. Семашка, В.М. Пічі. Каравела, Львів: «Новий світ». 2000. 334 с. 
participation in team events that will allow to remain in the art market or at least to distance yourself in art area. There are also foreign exhibitions, often of a scandalous temper, but not without artistic value, saturating the cultural area of these cities with a spiritual variety. Whereas in cities of lower cultural ranks, artistic life has either faded (due to the lack of financial support or lack of exhibit areas, or persons, who are able to demonstrate something), occasionally flashing with appearance of exhibits by students of the local art school or other educational institution.

The artistic life often concentrates around bright personalities, who are able to stimulate local initiative and actively fill the artistic area, provoking enough resonant discussions in mass media, art workshops or specific art galleries, as it with a certain frequency happens in Rivne in the Gallery of European Art "Euro-Art", in exhibition hall of the regional organization of the National Union of Artists of Ukraine or in other exponential halls.

Each period in society is inherent in the parallel existence of several forms of art. They are not esthetically equal, but there is always a need for them. After all, beside the esthetically developed audience there is always an audience, the esthetic development of which for different reasons will remain lower. Therefore, the issue of interaction between elitist and mass art is of interest. Significant of this era according to I. Chernova's ${ }^{3}$ definition is "the turn to the mass audience and its tastes, the kitsch apology, the formation of hedonistic esthetics of leisure, the growing role of esthetic simulacrums which neutralize taste preferences", on the one hand, on the democratization of culture, and on the other, on the devaluation experienced by art in the context of art market and show business, management and marketing, offsetting the specifics of the esthetic and artistic".

Interdependent development of technical means of dissemination of information and mass art is an important aspect of dominance of this activity. One of the most important factors leading to this is the process of globalization, which stimulates the unification of society, facilitating the seizure of new markets for the promotion of mass art in the contemporary cultural area. However, the functioning of an artist in modern society still remains relevant, despite the city where he is exhibited. Moreover, a regional artist feels all the negative factors like other members of society, but his creative problems are escalated by a number of other factors: high political tension in the country, which from time to time turns into social apathy, low artistic level of public, which should stimulate his artistic energy, various financial problems affecting

\footnotetext{
${ }^{2}$ Галерея європейського живопису «Євро-Арт». Режим доступу: http://euroart-gallery.rv.ua.

${ }^{3}$ Чернова I. Музичне виконавство у контексті реалій сучасної культури / Музична україністика: сучасний вимір: Зб. наукових статей. Київ, 2012. Вип. 5.
} 
both artist and public, which is potentially a consumer of his creativity in both visual and physical dimensions (buying his works - SV).

Let us try to identify the state of functioning of art and artist as a subject of artistic activity in the contemporary social and cultural area and to identify the factors which influence this situation. As a basis we will take the data of the poll "Artistic life of Rivne region”, conducted among Rivne artists, art critics and organizers of cultural area L. Churikova ${ }^{4}$ (the National Academy of Executives of Culture and Arts) according to the method of sociological research "Artistic life in Ukraine” of author's development by prof. O.Semashko (2005-2007).

Indicators such as professional education and respondents' age qualifications are of interest because their correlation provides relevant information for further interpretation of obtained data.

According to the poll materials, $68.6 \%$ of respondents have a professional art education and the artists' age rating is as follows: $15.6 \%$ (8 people) are young generation under 35 - that is, people whose age and creative experience make it impossible to actively express themselves, ignoring the action of social, including organizational and financial factors. However, the overwhelming majority of respondents - 49\% (25 people) fall into the category of "middle generation" (35-50 years), those who have organizational, artistic and creative experience, participation in various exhibitions, etc., so they should have everything that allows you to actively and artistically act in a particular cultural locus. Only $31.3 \%$ (16 people) of the survey are older people, over 50 years of age, those who has specialized education, multiplied by creative experience, which should contribute to their own creative self-realization. In other words, in fact, $80.3 \%$ of Rivne artists surveyed, or 41 (out of 51) artists have all reasons to be successful in the cultural area ${ }^{5}$.

The correlation of other data is also significant: almost $51 \%$ of local artists are on "creative breads" and 49\% hold positions in different organizations (mainly educational institutions), that is more than $50 \%$ of the regional department of the National Union of Artists of Ukraine independently chose art work as an important factor of their own self-realization. Therefore, more than 25 members of the local Union of National Union of Artists of Ukraine (out of 51 available) work mainly for artistic result, without overburdening themselves with uncreative, in their opinion, work.

At the same time, the 13 items of the questionnaire reflect the reasons which hinder their further creative self-realization, including: "low pay" -

${ }^{4}$ Чурікова Л. І. Проблеми розвитку образотворчого мистецтва на Рівненщині : результати соціологічного дослідження сфери художнього життя регіону. www.nbuv gov.ua/ portal/soc_gum/kis/2009_2/5. pdf.

${ }^{5}$ Ibid. 
72.5\%, "insufficient financial position" - 67.7\%, "workload with uncreative work" - 52.9\%, "insufficient level of management in art" - 47.0\%, "complication of the social situation in which it is not easy to express yourself creatively" $-43.1 \%$, etc ${ }^{6}$. In our opinion, these answers are incorrect. After all, the artists themselves chose their own path in life. For those who have a good age and experience in arts, these difficulties aren't new and predictable; and for young people they are also familiar, because it was formed in another social and cultural area, the time of the birth of so-called market relations. The examples with representatives, for example, the photo art of region, considered in the relevant sections of the dissertation, reveal another situation in which only one's own activity, desire to do something and subsequently gives a notable creative result. For example, it is about the work of O. Kharvat, O. Kupchynsky, O. Potyanok, O. Maistruk or any other of this category of artists, who are just as busy with "uncreative", in relation to art, work (business, teaching or journalistic activity).

The same can be said about the musical groups - "Silver Tertiary", whose leaders spend most of their time teaching in educational institutions; or about "Edelweiss" choreographic agency, which brings together more than 500 children of all age in their ranks, providing them with vivid creative selfrealization through many forms of self-realization they have. Of course, "any comparison is lame", but in other forms of art there are problems with public, level of its artistic preferences and tastes, system of art management in general ${ }^{7}$.

Among other reasons that hinder the development of fine arts, almost $53 \%$ of those interviewed said that "contemporary fine arts are too heavy on traditions, they do not renew their artistic means enough. "Such a high percentage of answers is completely incomprehensible and unmotivated because the fact of the existence of artistic traditions is determined by the number of those who profess or keep them, as well as the need to update the artistic means depends entirely on personality of artist. Only he determines whether to update or not to update his symbolic, semantic, formative system. How he does this is fully reflected in the viewer's reactions; and to some extent influences the fact of acquisition (or non-acquisition) of one or another of his works. By the way, at all times an artist was a standard, an example, who with a help of his work encouraged general public to art perception. At least, that was the role of artist back in Antiquity society! In our opinion, the role of financial factor concerning art today is exaggerated, because tickets to football matches, regular use of alcohol and other variety of modern costs are much more

${ }^{6}$ Чурікова Л. І. Проблеми розвитку образотворчого мистецтва на Рівненщині : результати соціологічного дослідження сфери художнього життя регіону. www.nbuv gov.ua/ portal/soc_gum/kis/ 2009_2/5. pdf.

${ }^{7}$ Ibid. 
expensive than the average work of art of regional level or visiting galleries, concert halls, museums etc.

The reproach about the spiritual needs of public can surely be done. However, an artist (and this should be inherent in all artists regardless of their creative self-realization) is called upon by the society in order to form these needs in a certain and necessary way. For an artist they will later eventually turn into a proper blessing in a form of a spiritual level of public, the frequency of visits to exhibitions, the purchase of works of art etc. The members of the Society of Art Exhibitions in Kyiv or other similar society in Kharkiv or Western Ukraine did it at that time (at the end of the 19th century). The most famous in the artistic context cities or artistic groups which functioned in those cities went the same way.

A high rating of values in the mentioned poll is among the reasons for the difficulties in the development of art in modern Ukraine, including Rivne region, $41.2 \%$ (21 persons), and $52.9 \%$ said that the main difficulties of art development is a fact of commercialization of artistic practice.

In our opinion, this data can only reveal the passivity of artists. After all, the country has long lived by new financial and cultural "standards", no matter how we treat to this, and any product, including intellectual, must not only be created, but also sold. Unfortunately, an artist himself has to be involved in this realization (quite often and this is another matter!). Business organizations, whose purpose will be PR campaigns for certain works of art, will not change the situation in any way, as they will try to promote works based on the pre-existing tastes of audience and "businessmen" themselves, without hoping to solve humanitarian issues - enhancing of artistic taste, forming the spirituality of viewers. The market or so-called market, is still a market, and it will dictate its rules; the issues of spirituality must be dealt by quite different organizations, including artists themselves. They have always been and hopefully will be in society throughout its further history. Moreover, there are enough halls in Rivne for such exhibitions, ranging from art halls of regional organization of the National Union of Artists of Ukraine ${ }^{8}$, the City House of Culture, the Universal Scientific Library, the Local History Museum, cozy enough (in cultural context) theater buildings and concert halls - two Academic theaters and Organ Hall (where the audience is concertrated and formed by many years of exponential and concert activity, is also able to evaluate the artistic and creative thought of artist) and, after all, the audience of Rivne art institutions of different levels of accreditation and art schools, and also to evaluate to a specialized institution, which is the Gallery of European painting "Euro-Art". This can be done in the

\footnotetext{
${ }^{8}$ Сайт НСХУ Рівненське обласне відділення. Режим доступу : https://nuau1938.wixsite.com/nuau/ronuau.
} 
majority for absolutely free (without rent or for a nominal price) and in return, though insignificant, maybe not be very deep, but in the overwhelming majority a positive, sincere reaction in mass media and discussion of grateful public during the exposure time. These organizations have the experience of arranging such events and also formed public by them, that is, prepared for artistic perception public. A high-quality cultural product at the regional level (the cost of a ticket to theatrical performances, cinema concerts, etc., and visiting exhibitions, presentations in regions is generally free) has unfortunately a low price for an artist, that is, it's accessible to the majority of local population in regions. Therefore, any talks about the inaccessibility of cultural services to an average spectator or listener, at least in Rivne region, is far-fetched and untrue. The same situation is in Volyn, Ternopil, Zhytomyr and Ivano-Frankivsk regions.

It is strange when analyzing the results of the survey we see a choise by local artists the alternative that "fine arts cannot reflect and comprehend the dynamism of social change", which $41.1 \%$ of respondents said and this raises a logical question about the role of an artist in contemporary society and to form not only the tastes of an average viewer, but also directors at allhierarchical levels. After all, this was the role of the artist in ancient society and with higher or lower value and the importance of this role has reached the present day. Although being acquainted with the works, for example, of local sculptors M. Yorysh ${ }^{9}$, M. Sivak, V.Sholudko ${ }^{10}$ or P. Podolets, this cannot be said at all.

They continue to hold a leading position in the popularity ratings among colleagues and they are leaders in participating in the cultural area and their own self-realization. They are the most popular in the contemporary cultural area of region. Thus they demonstrate a wide possession of expressive artistic means both in a form of detection and in a rating of popularity and participation in a change of regional cultural area. It's impossible to imagine the city of Rivne without the Muses on the building of Organ Hall and Chamber Music made by M. Sivak and our Independence Square without the monument to T. Shevchenko made by E. Mysko and P. Podolets, as well as the buildings of Hydraulic Engineering Faculty of National University of Water Management and Environmental Engeneering without the pedestal of G. Koroleva or the Palace of Culture "Tekstilnyk" without a monument to Rivne weaver $\mathrm{M}$. Yorysh or a number of sculptural busts and monuments to famous people

\footnotetext{
${ }^{9}$ М. Йориш. Енциклопедія сучасної України. Режим доступу : http://esu.com.ua/ search_articles.php?id=12996

${ }^{10}$ В. Шолудько. Режим доступу :https://uk.wikipedia.org/wiki/\%D0\%A8\%D0\%BE\% D0\%BB\%D1\%83\%D0\%B4\%D1\%8C\%D0\%BA\%D0\%BE_\%D0\%92\%D0\%BE\%D0\%BB\%D0\% BE\%D0\%B4\%D0\%B8\%D0\%BC\%D0\%B8\%D1\%80_\%D0\%91\%D0\%BE\%D1\%80\%D0\%B8\% D1\%81\%D0\%BE\%D0\%B2\%D0\%B8\%D1\%87.
} 
of Ukraine and Rivne region, including those built by V. Sholudko. This situation is inherent despite global, financial, organizational, methodological or dozens of other factors in every city or town and country in general. It is always possible to reflect social changes in any society not only by means of art, but also by any other artistic expression. Form and means are chosen by one who tries to respond to these changes - an artist himself. Nowadays each of the notable artists surely participates in numerous plein airs, inter-regional exhibitions and has the opportunity to find their own application ${ }^{11}$.

Responding to a questionnaire questions concerning the difficulties faced by native art, local artists also mentioned "underdeveloped art market, management" - $68.6 \%$, which is quite correct. However, this situation in our country and region will certainly not change by itself.

In this regard, we give the experience of Odessa, which at the end of the nineteenth century, wasn't different in anything pictorial and had undeveloped art market, and the reluctance of an average viewer to be interested in art didn't create a cultural area. However, with the help of the Association of South Russian Artists, created there at the end of the century under the influence of socially active activity of the Association of Mobile Art Exhibitions (St. Petersburg and similar, organized by Ukrainian V. Razvadovsky), his interference with cultural area in the city, the situation has changed radically, making Odessa one of the brightest cities of the empire in cultural and artistic context.

The same thing happened in Kharkiv (where M. Ivanova-Rayevska was a leader of the association) and in Kiev (led by M. Murashko) in the late 19th century, which, under the influence of cultural activity of local art organizations, formed art museums, artistic associations, special art periodicals, etc., in which the sprouts of professional art criticism could be realized and all the attributes of cultural life could be established, which distinguishes the true cultural center among other ordinary cities. Nowadays in a similar way, for example, in matters of raising public awareness, instilling and deepening his interest in books and reading in general, the United Kingdom, not to mention Sweden and even the former Baltic republics, has always been distinguished by ideological principles and spiritual needs. Therefore, the above-mentioned regarding the analysis of cultural and artistic life of region can only reveal the fact of the detachment of its carriers from the artistic life and their own passivity. 92.16\% (47 persons out of 51) of respondents did not answer the question "What are the most interesting artists of foreign fine art?" which is surprizing as to whether such an answer is really present. Its presence can

11 Крупеніна Л. В. Творча спілка як культуроутворюючий чинник міського середовища (на матеріалі діяльності Товариства південноросійських художників в Одесі на межі XIX - XX ст.): дис. ... канд. культурології: спец. 26.00.01. Сімферополь, 2009. 189 с. 
understood as ignorance of contemporary artists abroad by local artists ${ }^{12}$, reluctance to be concerned with actual problems of the development of the noncultural area, to focus only on their own problems, which are far from art.

However, there are often many local artists outside Ukraine who join the cultural area without any problems, having friends, relatives and colleagues. This process was not significantly affected even visa-free regime, received by Ukraine in 2017. Moreover, local artists are glad to accept and fully take care of them by foreign colleagues. Another thing is that both in 2007 and nowadays there is little awareness among artists of various artistic preferences regarding notable exhibitions in the world. This question can be solved at the level of the creative union, whose leadership has more information about certain cultural and artistic events in Europe and in the world. This issue can be assigned at least to one of its members with further information for the members. The local (regional) authorities recently find an opportunity to compensate for the holding of international plein airs, despite the lack of funds. One of respondents could not name art critics or believed that there aren't those ones in Ukraine (July, 2017). This answer is also doubtful, but there is another indicator which faces that local artists have a little interest in the theoretical aspects of art without paying attention to theoretical issues of art or they don't understanding what art criticism is. Such division of answers indicates that today there is no stable organization of artistic life in local regional art, there is a low level of relations between such subjects of artistic activity as an artist and an art critic. This trend is clearly evident according to the interviewer (in regional context), reflecting the low level of spiritual requests, professional skills of local artists and art critics ${ }^{13}$.

Undoubtedly, it is difficult to adapt to the present state of functioning of the vatiety of forms and the blurring of criteria regarding the essence of art in society and the role in this process of an artist; and for many people it's almost impossible to adapt. However, this is the rule of motion. It remains spiritually only an adapted or so powerful, cultural phenomenon, which is able to change the direction of movement to oppose existing forms.

Time after the poll has passed, of course, and the situation in country and in region has changed. However, it is not so fundamentally that the revealed remarks could be regarded as inadequate to its results.

Summarizing the above, it should be noted that the reason for the current negative state (or it's beter to say - intellectual tension) in the field of spirituality in country and the attitude to cultural practice in general, as it seems to a big part of ordinary citizens and artists in particular, is, apparently, that

\footnotetext{
12 Чернова І. В. Музичне виконавство в ситуації постмодернізму: автореф. дис. ...
} канд. миств.: 17.00.01. Львів, 2007. 20 с.

${ }^{13}$ Ibid. 
there are many regional artists (and not only regional ones), art historians or other persons. They are involved in the cultural area and they actually determine the landmarks in the development of this art. They are people of older age and people with diferent scale of value orientations and vision of this movement and it is often important to emphasize - people who don't want and are not able to change the motion vector. Therefore, they are oriented in their cultural practice mainly to the socialistic orientations and in this case consumer (passive in relation to personal participation in the cultural process - S.V) orientations (emphasize that this is an analysis of a specific regional area). Their example of a little noticeable interference with the cultural area only harms this art. After all, our country has objectively chosen a non-socialistic way of development, on which completely different laws apply and a new system of cultural coordinates is formed. Not knowing or weighing those laws in this process will only harm both artist and art. Nowadays it happens in many areas of country's cultural activity, especially in the administrative areas, which are the main cause of misunderstandings and the lack of noticeable movement forward ${ }^{14}$.

According to J. Matveicheva “... Despite the fact that in order to adapt the area of culture to new social and economical conditions, a number of normative and legal acts have been developed and adopted at the state level, which improve the development of the cultural infrastructure of the society, and the established priorities in this matter have not been formed yet. It's mostly about intentions".

\section{New forms of cultural activity as a mean of social apathy overcoming}

In view of the situation, quite plainly depicted in the previous paragraph, the group of the city's artistic intellectuals, initiated by the Department of Culture and Tourism of the City Executive Committee, colleagues of the Department of Cultural Studies and Museum Studies of Rivne State Humanities University, including the author of this article, decided to intervene in the cultural area and change the situation. Moreover, the cultural area in the city is formed: there are two music schools, one art school (there are similar organozations in each district of region), departments of the National Creative Unions, the Institute of Arts, which includes the Department of Arts and Crafts; two exhibition halls, one of which belongs to the Regional Department of the National Union of Artists of Ukraine.

The activity of the Department of Architecture of National University of Water Management and Nature Engeneering is noticeable. Their specialists provide a change of cultural area with a help of design and construction of monuments of monumental art. One of its repeatedly mentioned employee

${ }^{14}$ Виткалов С.В. Рівненщина: культурно-мистецький потенціал в парадигмах сучасності: монографія. Рівне: ППДМ, 2012. 412 с. 
sculptor P. Podolets ${ }^{15}$ was selected by open competition for the post of Head of the Regional Organization of the National Union of Artists of Ukraine in February 2017.

The staff of the Department of Cultural Studies and Museum Studies of Rivne State Humanities University holds All-Ukrainian (International) scientific and practical conferences of cultural and artistic orientation for 15 years in a row. They gather from 300 to 500 participants and issues of the national and cultural movement annually. European integration processes are the subject of discussion. Similar events are organized by the Department of Architecture of National University of Water Management and Nature Engeneering, the Regional History Museum, which together with Rivne Regional Center for Folk Art is the founder of "Museums of one village", "Museum guests" and other cultural and folklore events, which were mentioned and during which the issues of the development of folk cultural practice are the subject of particular attention. The named organizations are filiations of the department and some of their staff are teachers of the department, which helps to organize all kinds of activities better. It is facilitated by the fact that the director of the mentioned Rivne Regional Center for Folk Art (RRCFA) has been leading the All-Ukrainian Board of Directors of similar centers of Ukraine for several years in a row. His cooperation with the members of the department makes it possible to raise the theoretical ground for cultural and artistic activities and to widen such experience, search activities and involve student youth in all territories of country. Under the influence of this activity (taking into account the originality of the cultural and artistic local space) the periodical magazine "Folk Art of Rivne Region" was founded, which is published with the support of RRCFA. Its edition and layout is carried out by dissertant. In cooperation with RRCFA and the staff of the Department (together with the dissertant) the Polissya Culture Research Program was developed, which resulted in the publication of many fundamental scientific works, including the already mentioned monographs, as well as: T.Parkhomenko "Calendar customs and rites of Rivne region, 2 e. Volyn Charms, (2008), collective monographs: Ethnoculture of Rivne Polissia. Rivne, 2010. 360 p., Arts and crafts of Rivne region. Rivne, 2011. 259 pp., L. Kostyuk, U. Bukailo Traditions of Polissia haze. Rvne, $2016^{16}$. 156 p. etc. All-Ukrainian scientific and practical conferences on the development of haze weaving (2015), the activities of the Historical Volyn Consortium (2010) were held. Experts from Ukraine and Belarus participated in this work.

15 Виткалов С.В. Рівненщина: культурно-мистецький потенціал в парадигмах сучасності: монографія. Рівне: ППДМ, 2012. 412 с.

${ }^{16}$ Історична Волинь і проблеми духовного відродження України: матеріали Івсеукр. наук.-практ. конф., 10-11 верес. Актуальні питання культурологї̈. Рівне : О. Зень, 2010. Вип. 9/ 
The printing of various methodological literature for Ukrainian cultural workers and students is greatly expanded. The Center began to actively search for new forms of activity not only among employees of the leisure area, creating the first in Ukraine a chain of cultural and leisure complexes, which he methodically provided, but is also focused on inter-regional cultural contacts.

Nowadays the culture workers of region with the support of Center started an interesting project - exchange trips with samples of their own traditional cultural heritage in the regions of Ukraine. For example, on November 25, 2015 (and further similar contacts continued on schedule) a presentation of such a project was demonstrated by employees of a similar center from Ternopil in Rivne. The original was that all exhibitors are not professionals in the cultural field. These are doctors, teachers, workers of other field of national economy. Icon painting, instrumental creativity, artistic embroidery, singing are their hobbies. However, this kind of activity allowed them not only to visit art samples in many countries, convincing the population of these countries in the uniqueness of regional creativity, in the brightness of Ukraine in general, but also for some of these became the second profession.

Such projects not only gather the population around. In this case, the ideas of preserving cultural heritage demonstrate a powerful cultural potential of our country, which is strong in its regions. Such activities will help to unite around one idea, which is the preservation of cultural heritage, to become stronger during this difficult time.

In recent decades Rivne region has regained its past glory with the intensive development of folk culture. The reason for this is the fact that popular culture, which has in fact receded in Europe in the past, has intensified the interest of citizen of the same Europe to those countries where everything is preserved, and most importantly, it continues to be cultivated, despite the lack of material and technical facilities and, in fact, the state's interest in these processes. Ukraine (at least its western part) continues to show this distinctiveness in cultural progress aimed at keeping traditional national and cultural features.

Other factors helped this revitalization of the festival movement (120 events were conducted, for example, in Rivne region in 2012), which stimulated the arrival of a considerable number of guests from other countries, which still have an interest in folk cultural practices. By the way, a similar situation is typical for Volyn and to a lesser extent, for Zhytomyr or Ternopil regions, where the ethnological factor is a unifying factor of population. Therefore, the social aspect of its living is specific to the second half of the nineteenth century and it has acquired completely different features already in the in the newest day. The appearance of people from other social, cultural and political backgrounds, who are not indifferent to the preservation of folk 
traditions during the festival events or scientific conferences, only stimulated and raised the Ukrainians in their own eyes regarding the cultural potential of their own intangible cultural heritage.

Although the festival movement has slowed down a bit in recent years (since 2017), concentrating on separate internationally significant events for region (folk studies - "Kolyada”, “... Rolling Bag”, professional music "The Wonderful Organ World", "Ukraine - the USA: Partnership by the organ”, “Art Jazz Cooperation”, children's creativity - "Orchestra’s copper sounds...”), as their number decreased due to known financial and social and political factors. In general, this movement acquired professionalization and brought Rivne region into the number of "festival" international centers ${ }^{17}$.

This was greatly facilitated by the fact that the Regional Philharmonic started a number of original programs with invitation of foreign performersinstrumentalists (Czech Republic, the USA, Poland), who are known to be actively engaged in pedagogical or educational public activity, in addition to their own concert activity and significantly absorbing the spiritual culture of the population. Constant contacts of regional performers with representatives of foreign artistic elite changed their attitude to their own cultural activity in general. This all has changed the attitude to spiritual issues. These opportunities have deepened and with the help of art organization created in 2011 as a private gallery of European art "Euro-Art", which not only led the exhibition activity, but also accumulated considerable potential in its collections of works of fine art from different eras and countries. It formed a group of staff members of the Department of Cultural Studies and Museum Studies, who also transformed the halls of the gallery into a filiation of the department and began to carry out educational activities among schoolchildren and students. The gallery became an exhibition center for works of local artists, art collections of leading craftsmen of the world, discussions of cultural and artistic issues, organizer of various "Round tables", where issues of the essence and ways of development of contemporary art, national cultural heritage, involvement of the local population became its leading activity.

There were 57 exhibitions in the halls of the gallery and the club cafe, the expositions of which were viewed by 17,723 visitors. The "Euro-Art" activity is highlighted by mass media - 23,457 messages can be found in newspapers, magazines, TV projects and Internet ${ }^{18}$.

${ }^{17}$ Виткалов С.В. Фестивальний рух як культурний феномен сучасності: спроба аналізу регіонального вектора. Культура Украӥни: серія «Культурологія»: зб. наук. пр. / Харків. держ. акад. культури: за заг. ред. В.М. Шейка. Харків, 2016. Вип. 52. С. 182-190.

${ }^{18}$ Виткалов С.В. Культурна сфера Рівненщини як сегмент їі духовного поступу (галерея європейського живопису «Євро-Арт»). Вісн. Харків. держ. акад. культури: «Культура Украӥни». Харків, 2014. Вип. № 44. С. 44-51. 
The journalistic activity of the members of the above mentioned department, including the author of this work, whose assets are almost 240 journalistic intelligence, mainly reviews of cultural events and reviews of individual events conducted during the last 9 years. Along with existing literary and artistic monthly magazines "Pogorina" and "Volyn" another monthly magazine with All-Ukrainian area of distribution - "Art facets" appeared in the city. The author led a special column in it for almost two first years of existence, promoting the popularization of art among the population. He is also the initiator of a series of TV shows on similar issues on the regional "Rhythm" TV channel, where he has tele-recorded almost 60 copyright programs with popular masters of arts of country and region, expanding his notion of cultural potential and area not only to the local public, but also to professional artists and amateurs arts and crafts.

The members of the department (Assoc. Prof. L. Kostyuk and the author of this article) initiated the foundation of G. Kosmiadi Art Prize (the artist who lived and worked in the city of Rivne in the 20-40s of the 20th century, leaving more than 5,000 paintings), having joined the organizing committee. This prize and other ones like I. Sveshnikov Prize (for achievements in archeological or archeographic activity), G. Leonchuk Prize (for achievements in national embroidery and national regional culture), Scholarships of the Head of Regional State Administration and the Head of the Regional Council and other honors to the artists are an incentive for artistic activity and fellows from the visual environment, and art historians for the development of national historiography and public history. The regional Programs "Provision of Local People with Ukrainian Book", which publishes historical, cultural and fiction literature or artistic programs implemented at the expense of the public budget. They are also means of stimulation the initiative and expanding the regional aspect of printed production.

I will also note that the situation in the city required significant changes and to lead the administration of the Department of Culture and Tourism of Rivne City Executive Committee came a bright organizer of cultural activity T. Maksimenko, whose organizational and cultural activities of his team caused significant improvement in the city's cultural infrastructure, including their grant for more than 0.5 million EUR received in the European Union (Belgium) for the "Rivne Mysterious Dungeons" ${ }^{19}$ program allowed powerful archaeological research in the city. It was only during 2018 that artifacts were found that significantly pushed the boundaries of perception of ancient times in the territory of Rivne region and made it possible to actually complete the

\footnotetext{
${ }^{19}$ Таємничі підземелля. Режим доступу : https://euprostir.org.ua/grantees-mysteriousrivne-dungeons.
} 
creation of an underground museum of region, whose organizational and technical capabilities exceed what is today in the museum and in a "reserve" set of region. His report at the fifteenth International Conference "European Cultural Area and Perspectives of Ukraine", held on the basis of the above mentioned department (14-15th November, 2019) in the presence of the heads of administrative organizations of the regional state administration significantly changed the attitude to everything that a person can, and also became an alternative terrible statistics obtained by the Department of Family and Youth as a result of their own research into the psychological state of young people in region (over $8 \%$ of whom think of suicide).

As the cooperation of the staff of the Department of Cultural Studies and Museum Studies of the RSHU and the administrative organizations of Rivne Regional State Administration (Departments of Culture and Tourism, Education and Science, Family and Youth) through constant participation in international scientific and practical conferences, involvement of the staff of the departments in development of tourist routes, organization, edition of collective monographs, cultural almanac, work of the faculty of advanced training of cultural workers of the region etc., promotes the improvement of spiritual climate, widens the contacts of the RSHU with cultural institutions, improves the quality of youth education. Under the influence of this activity the spiritual climate of region has improved. Visiting art exhibitions and museums has become the norm by pupils and students. The gallery has increased the number of its own exhibitions as well as expanded the purchase of works of art of local artists, exhibiting the latest in its halls, opening original art-style cafes, where art lovers and artists have opportunities for communication. The appearance of Chinese or Korean, as well as Lviv, Lutsk, Uzhgorod or Kiev art experts, who are increasingly organizing art exhibitions of artists from regions of our state, has become a characteristic feature of our city today ${ }^{20}$.

A separate jazz-bluss cultural and entertainment complex was built in 2012 at the expense of jazz art patrons in city to hold creative meetings, concerts and jazz festivals. That is why the city becomes the center of world jazz at the end of August. Together with Lutsk our city continues to support this interest.

The daughter of above-mentioned emigrant artist N. Sannov-Kosmiadi (born in 1924), purchased a historic building having moved to the city. She financed its renovation and transformed more than $200 \mathrm{~m}^{2}$ of its area into the Art Studio of G. Kosmiadi and donated to Rivne Regional Museum of Local History, placing a significant part of her father's cultural heritage there.

\footnotetext{
${ }^{20}$ Наукові заходи : http://hudped.rv.ua/2018/11/16/mizhnarodna-konferenciya-v-rdgu.
} 
Under the influence of this activity, the artists began to make significant gifts of their own works to the above mentioned local museum (from 30 to 70 paintings after the ending of personal exhibitions). A part of G. Kosmiadi's ${ }^{21}$ collection (5000 works of art) has returned to the city. The process of exporting works of art abroad was almost completely hindered. On August 6th, 2018, Volyn artist V. Krasyoha demonstrated a unique collection of more than 40 paintings by "The Athos Shrine" in the exhibition hall of Rivne Filliation of the National Union of Artists of Ukraine. This collection was painted during his 60 days of stay in the center of Orthodoxy world and also made under the influence of these improvements in cultural city infrastructure.

He created high-quality exhibition areas and the City House of Culture, which, in addition to renting its own areas for touring, began to position itself as an important center for the demonstration of works of art (mainly international biennale) and photography, as the city has been the center of international photo festivals "On Pokrov Day" for more than 20 years. The representatives of 3045 countries annually demonstrate the creative potential of artists, multiplied by the technical capabilities of camera during those festivals.

Therefore, the absence of an art museum in Rivne was largely offset by the gallery and named types of organizational and cultural activities of artists and organizers of the cultural area, making it a cozy and culturally rich center of Western Ukraine. The Gallery completed the process of cultivation the spiritual area of region, giving it specific professional attributes.

\section{CONCLUSIONS}

Tne analysis of the city's cultural situation in recent years and an attempt to intervene in its change have shown that a sufficiently strong intellectual potential has been formed in Rivne and the city has something to be proud of, as the International Festivals "MUSICA VIVA ORGANUM" and "Ukraine - the USA: International Partnership at the Organ", "Metal heart of Ukraine” and "Rivne. Summer. Music", conducted only in August 2019 at the concert halls of Rivne, numerous art exhibitions and the acquisition by private collectors of art paintings and their permanent display in the halls of the city, the International Festival "Photo-rotation on Pokrov Day", the appearance of numerous monograph editions, their constant discussions, creation of educational institutions on the basis of the gallery, implementation of large-scale excursion activities, conducting international summer schools of jazz art in the city etc., as well as involving students from different educational institutions in this process - all this is a striking page in expanding international and intercultural contacts

21 https://krapka.rv.ua/2017/05/24/nadiya-kosmiadi-stvoryla-v-rivnomu-art-atelye-svogobatka-foto/ 
of our country with the outside world, for which young Ukrainian republic is positioned as an intelligent state, which places high art in its own cultural priority, which will not allow it to stumble among regular quarrels and the profound unprofessionalism of the national political "beau monde", which is mostly concerned with self-preservation.

\section{SUMMARY}

The article is devoted to the consideration of the current state of cultural life of a typical Western Ukrainian city of Rivne. The materials of sociological researches, conducted by Kiev scientists in region, are analyzed for the attitude of the artistic intellectuals to the national and cultural changes caused by the Act of proclamation of the state independence of the country. On this basis, the author's own attitude towards the respondents' answers is presented. Their critical analysis based on the nature of the organization of the cultural area of the city has been implemented. The ways of creative work of artists, based on their participation in professional associations, the level of professional education, artistic experience and age are revealed. The leading forms of activity of organizers of cultural area of the city, aimed at improving the spiritual climate and positioning the city of Rivne in the system of cultural coordinates of the country, are revealed.

\section{REFERENCES}

1. Vytkalov S. V. Interv'yu, provedeni $\mathrm{z}$ kuratorom halereyi yevropeys'koho zhyvopysu "Yevro-Art" L.K. Kostyuk u hrudni 2016 ta lystopadi 2019 rr. Pryvatnyy arkhiv avtora.

2. Vytkalov S.V. Kul'turno-mystets'ka Ukrayina v rehional'nykh vymirakh: monohrafiya [Cultural and artistic Ukraine in regional dimensions: monograph] Rivne: M. Dyatlyk, 2014. 362 s. (in Ukraine)

3. Vytkalov S. V. Spilkuvannya narodnykh umil'tsiv Ukrayiny prodovzhyly u Rivnomu [Communication of folk craftsmen of Ukraine was continued in Rivne]. Volyn', 2015. Vol. 43.4 hrud. (in Ukraine)

4. Vytkalov S. V. Suchasni aspekty doslidzhennya ta pobutuvannya "serpankovoho tkatstva". Materialy do ukrayins'koyi etnolohiyi (IMFE im. M. Ryl's'koho NANU) [Modern aspects of research and life of "veil weaving"]. 2015. Vol. 14 (17). (in Ukraine)

5. Istorychna Volyn' i problemy dukhovnoho vidrodzhennya Ukrayiny: materialy I vseukr. nauk.-prakt. konf., 10-11 veres. 2010 r. Aktual'ni pytannya kul'turolohiyi [Volyn Historical and Problems of Spiritual Revival of Ukraine: Materials of I All-Ukrainian]:. Rivne : O. Zen', 2010. Vyp. 9. 171 s. (in Ukraine) 
6. Krupenina L. V. Tvorcha spilka yak kul'turoutvoryuyuchyy chynnyk mis'koho seredovyshcha (na materiali diyal'nosti Tovarystva pivdennorosiys'kykh khudozhnykiv v Odesi na mezhi KhIKh-KhKh st.) [Creative union as a cultural factor of the urban environment (on the material of activity of the Society of South Russian artists in Odessa at the turn of the 19-20th centuries)]: dys...kand. kul'turolohiyi: spets. 26.00.01. Simferopol', 2009. 189 s. (in Ukraine)

7. Matvyeicheva Yu. O. Rehional'na kul'turna polityka ukrayins'koyi derzhavy doby nezalezhnosti (na prykladi Donets'koho rehionu) [Regional Cultural Policy of the Ukrainian State of Independence Time (on the example of Donetsk region)]: avtoref. dys...kand. kul'turolohiyi: 26.00.01. Kyyiv : NAKKKiM, 2014. 21 s. (In Ukraine)

8. Pershyy mizhnarodnyy plener "Istorychna Volyn"” vidbuvsya na Rivnenshchyni [The first international plein air "Historical Volyn" was held in Rivne region]. Volyn', 2017. No. 1329. 26 lyp. (in Ukraine).

9. Chernova I. V. Muzychne vykonavstvo v sytuatsiyi postmodernizmu [Musical performance in the situation of postmodernism]: avtoref. dys. ...kand. mystv.: 17.00.01. L'viv, 2007. 20 s. (in Ukraine).

10. Churikova L. I. Problemy rozvytku obrazotvorchoho mystetstva na Rivnenshchyni : rezul'taty sotsiolohichnoho doslidzhennya sfery khudozhn'oho zhyttya rehionu [Problems of the development of fine arts in Rivne region: results of a sociological study of the area of artistic life in region]. www. nbuv. gov.ua / portal / soc_gum / kis / 2009_2/5. pdf.

\section{Information about the author:} Vytkalov S. V., Doctor of Cultural Studies, Professor of the Department of Cultural Studies and Museum Studies Rivne State Humanitarian University 12, Bandera Str., 33028, Rivne, Ukraine 